\title{
Quality characteristics of the carcass of Beni-Guil sheep, a Protected Geographical Indication certified product of Eastern Morocco: Preliminary study
}

\author{
Kamal Belhaj ${ }^{1,3, *}$ Farid Mansouri, ${ }^{1,2}$ Aziz Tikent ${ }^{1,3}$ \\ Abdellah Ouchatbi ${ }^{3}$ Mohamed Boukharta ${ }^{4}$ \\ Caid Hana Serghini ${ }^{1}$ Ahmed Elamrani ${ }^{1}$
}

\section{Keywords}

Beni-Guil sheep, carcasses, meat quality, designation of origin, Morocco

Submitted: 21 December 2018

Accepted: 27 October 2019

Published: 24 February 2020

DOI: 10.19182/remvt. 31843

\begin{abstract}
Summary
The objective of the study was to evaluate, for the first time, the qualitative, objective and subjective characteristics of the carcass and meat of the Beni-Guil sheep breed, originating in Eastern Morocco. The study was conducted with 105 ewes and ewe lambs with a mean age of 21.5 months (8-36 months), and a mean weight of $32.55 \mathrm{~kg}$. pH measurements were taken one hour and 24 hours after slaughter. The mean values obtained were 6.76 and 5.78 , respectively. The mean hot (HCW) and cold (CCW) carcass weights and corresponding yields were $15.82 \mathrm{~kg}(48.6 \%)$ and $15.52 \mathrm{~kg}(47.7 \%)$, respectively. Shrinkage loss was $1.9 \%$. Linear measurements showed that the Beni-Guil had a mean carcass length $(\mathrm{K})$ and width $(\mathrm{G})$ of 63.7 and $17.3 \mathrm{~cm}$, respectively, with a carcass compactness index $1(\mathrm{G} / \mathrm{K})$ and $2(\mathrm{CCW} / \mathrm{K})$ of 0.27 and $243.60 \mathrm{~g} / \mathrm{cm}$, respectively. Finally, according to the EUROP sheep carcass classification grid, the carcasses examined showed conformations between fairly good $(\mathrm{O})$ and good $(\mathrm{R})$, a bright red color, a firm white fat cover, and a fatness score of 3.42. The results highlighted the characteristics of the Beni-Guil ewe carcass, which are sought by professionals and consumers.
\end{abstract}

- How to quote this article: Belhaj K., Mansouri F., Tikent A., Ouchatbi A., Boukharta M., Serghini C. H., Elamrani A., 2020. Quality characteristics of the carcass of Beni-Guil sheep, a Protected Geographical Indication certified product of Eastern Morocco: Preliminary study. Rev. Elev. Med. Vet. Pays Trop., 73 (1): 21-26, doi: 10.19182/remvt.31843

\section{INTRODUCTION}

In Morocco, the livestock sector is an essential asset in terms of agricultural turnover. It plays a very important role in rural socioeconomic development including food supply, employment, soil fertilization, and crop production. Livestock production systems range from intensive to

\footnotetext{
1. Department of Biology, Faculty of Sciences, University Mohammed First, BP 717, 60000 Oujda, Morocco.

2. Laboratory of Biochemistry, National Agency of Medicinal and Aromatic plants, Taounate, Morocco.

3. Veterinary Service, National Office for Food Safety, Oujda, Morocco.

4. Institute of Agricultural Industries, High School of Charlemagne, Huy, Belgium.

* Corresponding author

Tel.: +212 707789 094; Fax: +212536500603

Email: belhaj.kama190@gmail.com
}

extensive and mainly involve sheep and goats. The Moroccan national sheep flock is estimated at 29 million head (HCP, 2017) among which 99\% depends essentially on pastures and fallows (Boujenane, 2005). Sheep livestock is generally destined for meat production where the majority of the males are intended for the feast of the sacrifice, and about $25 \%$ of female lambs are reserved to replace the elderly ewes. The rest are fattened and intended for slaughter to supply the red meat markets throughout the year. Sheep meat production is estimated at 130,000 tons/year, representing $11 \%$ of the total national meat production (HCP, 2017). The highlands of Eastern Morocco are covered with a steppe ecosystem. In this region, sheep breeding represents the main agricultural activity that accounts for more than $17 \%$ of the Moroccan ruminant population (Boulanouar and Paquay, 2006). The production system is chiefly a semi-extensive to extensive system, based on pastoralism with transhumance practice, grazing sites being typically lowlands in winter and highlands in summer.

The Beni-Guil breed is a medium size sheep with phenotypic characteristics including a white fleece, glabrous and brown limbs, head and belly (Figure 1). This breed prevails in Eastern Morocco with around 


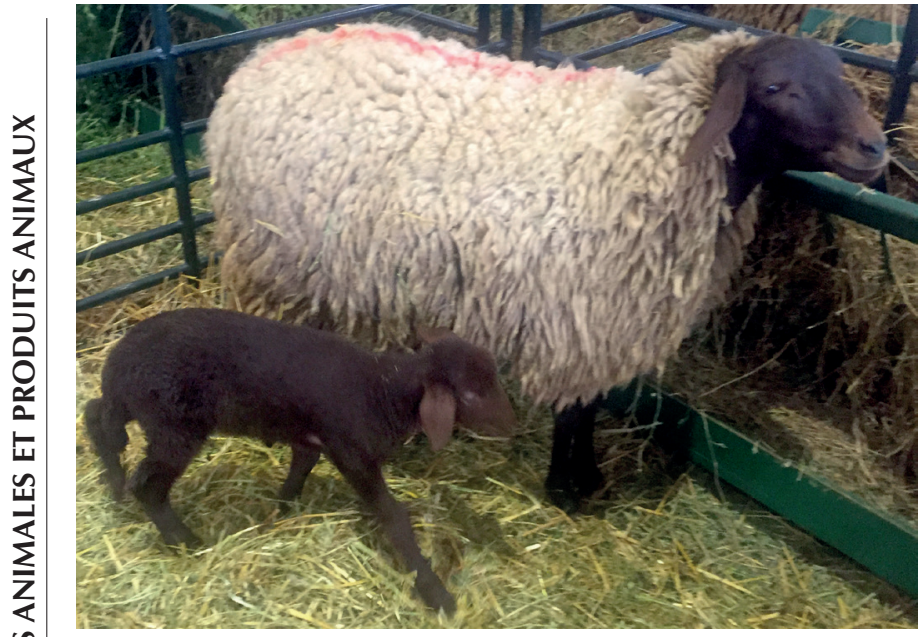

Figure 1: Beni-Guil ewe (18 months old) with its lamb in Eastern Morocco. (c) K. Belhaj

two million head (ANOC, 2018). The Beni-Guil has been integrated in the national program of genetic improvement since 1980. The aims are the preservation of local breeds, genetic improvement, and increase in red meat production (Boulanouar and Paquay, 2006). This program is operated by the National Association for Sheep and Goat breeders (ANOC), which currently includes 1719 breeders of Beni-Guil sheep located in the main grazing areas of Northeastern Morocco.

The Green Morocco Plan, led by the Ministry of Agriculture since 2008, enabled local agricultural products to benefit from labeling such as the Protected Geographical Indication (PGI) and the Protected Designation of Origin (PDO or organic farming) in order to preserve and promote rural agriculture breeding systems. The PGI certificate refers to agricultural products and foodstuffs whose characteristics are linked to the geographical areas where at least their production and/or processing took place. Beni-Guil sheep meat is one of the most popular ovine meat in Morocco. Since 2011, it has the PGI label because of its organoleptic and nutritional qualities (Belhaj et al., 2018). There are many studies about this breed, but they mainly investigate husbandry practices such as mating, lambing, and weaning (Guessous et al., 1989; Boujenane et al., 1998; Boujenane, 2005). On the other hand, apart from consumers' appreciation, there is little data on Beni-Guil carcass and meat quality. In meat markets, it is known that the meat color, carcass fat cover color and muscles development are the main quality parameters perceived by professionals and consumers for meat purchase.

Despite PGI labeling, additional research-based data is needed to promote scientifically this breed, which was the goal of this study. The study was thus carried out to determine the subjective and objective characteristics of carcasses of Beni-Guil ewes and lambs.

\section{MATERIALS AND METHODS}

\section{Animal material}

Animals in Eastern Morocco are mainly reared on natural highlands in an arid to semi-arid environment. The lambing season mainly occurs from September to December. The average lambing rate is $98 \%$ and the mortality rate from birth to weaning is $2 \%$. Apart from natural pastures, ewes' diet is supplemented with 150-250 g per day of alfalfa hay and barley during droughts, connecting periods, and at physiological stages such as at the time of preparation for breeding (flushing) and lambing (steaming). Four weeks before parturition, ewes receive barley supplementation to avoid abortions, as well as to improve milk production and quality. Fifteen days after lambing, the lambs are vaccinated against enterotoxemia. In the first two months of age, they stay in the sheepfold during the day and receive a supplement based on barley and alfalfa hay ad libitum. In the third month of age, they are reared with their mothers until weaning at the age of three months. They graze on natural grassland pastures with additional feed based on barley (100-120 g/day) and hay. Before slaughter, the lambs undergo a finishing phase of 45 days based on barley $(1-1.5 \mathrm{~kg} /$ day). They have free access to water and mineral supplement in the form of lick blocks.

One hundred and five carcasses of Beni-Guil ewes and ewe lambs were examined. They had been randomly selected from two slaughterhouses between February and June, 62 in Oujda and 43 in Jerrada, in Eastern Morocco (Figure 2). Sheep belonged to ANOC members (nine farms randomly chosen) and their mean age was about 21.5 months (8-36 months). The animals underwent a resting period under a water diet for 16-24 h before slaughter using the Halal method. In the first hour postmortem, the hot carcass weight $(\mathrm{HCW})$ was recorded. Carcasses were kept in the slaughterhouse at ambient temperature for 3 to $4 \mathrm{~h}$. They were then transferred into a cold storage room at $6^{\circ} \mathrm{C}$ for $20 \mathrm{~h}$. The cold carcass weight (CCW) was recorded $24 \mathrm{~h}$ postmortem.

\section{Objective carcass measurements}

The live weight (LW), HCW and CCW were used to calculate the hot and cold carcass yields (HCY and CCY, or hot and cold dressings, respectively), using the following formulas: $\mathrm{HCY}=(\mathrm{HCW} / \mathrm{LW}) \times$ 100 and $\mathrm{CCY}=(\mathrm{CCW} / \mathrm{LW}) \times 100$. The hot dressing is the economic yield and the cold dressing is the commercial yield.

The percentage of shrinkage loss was calculated thus: (HCW - CCW) $\times 100$ / HCW according to Carrasco et al. (2009). $\mathrm{pH}$ measurements were taken one hour ( $\mathrm{pH} 1)$ and 24 hours postmortem (pH24) in the longissimus lumborum muscle between ribs 12 and 13, by a portable $\mathrm{pH}$ meter (pH/Cond 340i WTW, Weilheim, Germany) equipped with a penetration electrode.

The meat color was measured 24 hours postmortem on the carcass fresh surface, precisely on the longissimus lumborum (between ribs 11 and 13) with three readings for each carcass using coordinate indices: $\mathrm{L}^{*}$ (lightness) $\mathrm{a}^{*}$ (redness) and $\mathrm{b}^{*}$ (yellowness). These coordinates were determined by a Chromameter (Konica Minolta CR400). To determine the myoglobin concentration and chemical status chromaticity $\left(C^{*}=a^{* 2}+b^{* 2}\right)^{0,5}$ and hue angle $\left(\arctan \left[b^{*} / a^{*}\right]\right)$ were calculated according to Calnan et al. (2016).

Carcass linear measurements (Figure 3 ) were taken 24 hours postmortem according to Colomer-Rocher et al. (1988). Length (K) and width $(\mathrm{G})$ of carcasses were measured as well as leg length $(\mathrm{F})$. According to Colomer-Rocher et al. (1988) and Alexandre et al. (2008), the carcass and the leg compactness indexes (CCI1, LCI), were expressed as the $\mathrm{G} / \mathrm{K}$ and $\mathrm{G} / \mathrm{F}$ ratios, respectively. A second method based on the cold carcass weight and carcass length was used to determine the carcass compactness index (CCI2), as follows: $\mathrm{CCI} 2=\mathrm{CCW} / \mathrm{K}$ (Cezar and Sousa, 2007).

\section{Subjective carcass measurements}

Sheep carcasses were subjectively scored by a trained assessor under the supervision of a veterinarian, according to notation scales: i) the fatness scale $(1=$ very low, $2=$ low, $3=$ average, $4=$ high, $5=$ very high) (Colomer-Rocher et al., 1988; D’Alessandro et al., 2013); ii) the conformation scale from 1 (poor) to 5 (excellent) according to EUROP classification ( $\mathrm{E}=$ excellent, $\mathrm{U}=$ very good, $\mathrm{R}=$ good, $\mathrm{O}=$ fair, $\mathrm{P}=$ poor) (Colomer-Rocher et al., 1988; D'Alessandro et al., 2013); iii) the carcass color according to European Union photographic standards $(1=$ very light red, $2=$ light red, $3=$ bright red, 4 = dark red) (Moëvi, 2006); iv) the cover fat quality according to 


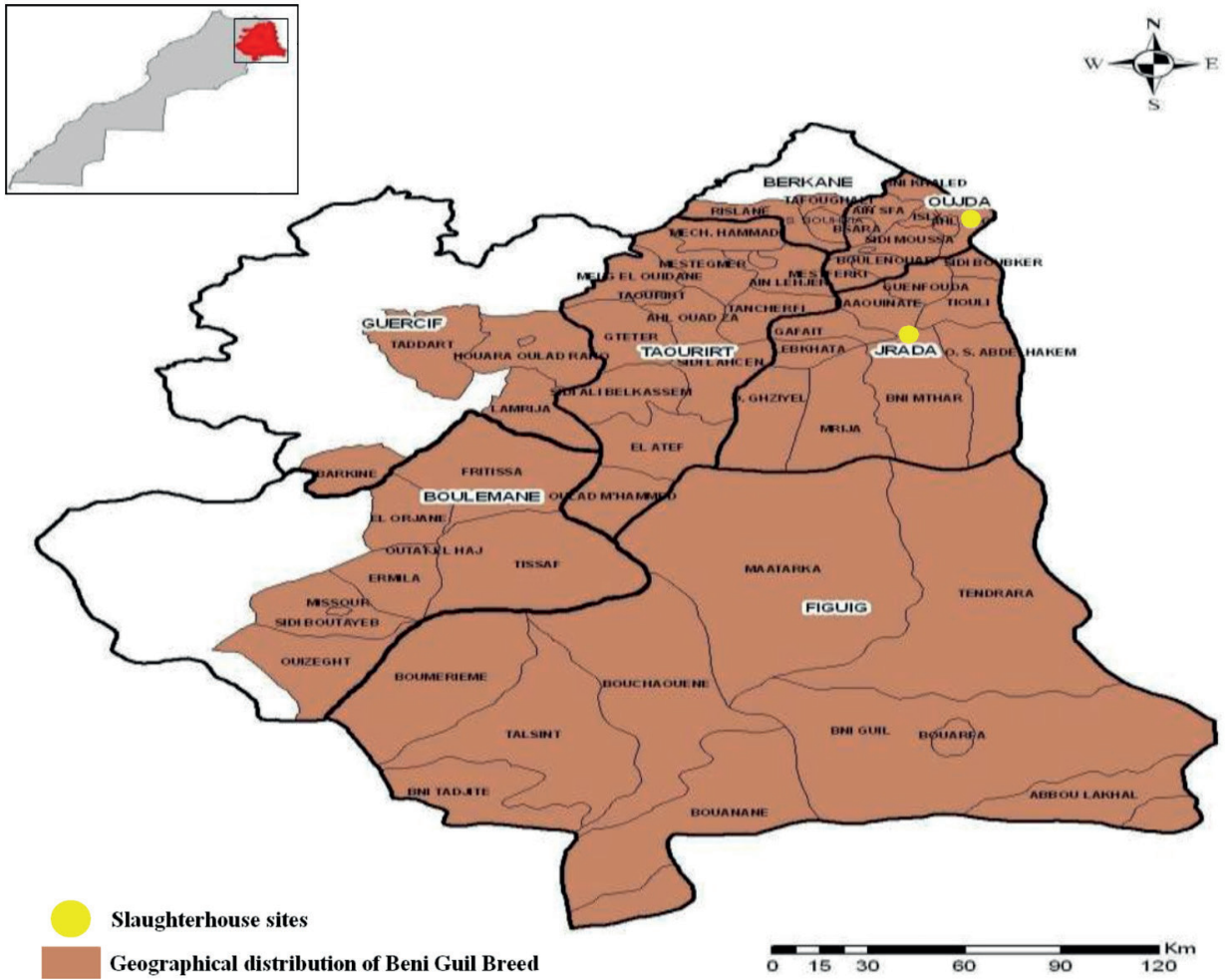

Figure 2: Eastern Morocco (in red and enlarged) showing the distribution of the Beni-Guil sheep breed and the localization of the slaughterhouses of the study area. (c) Adapted by K. Belhaj

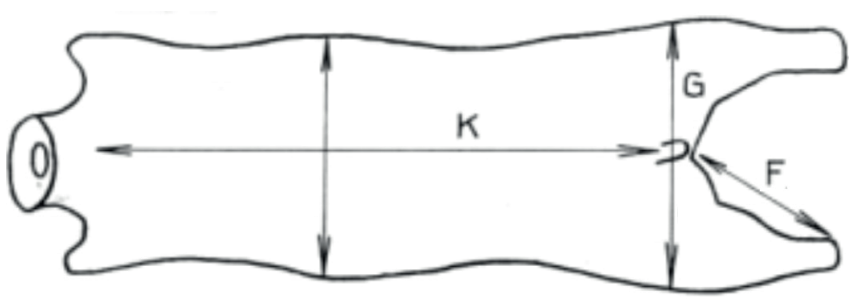

Figure 3: Zoometric linear measurements of the Beni-Guil ewe carcass. K (length): $63.7 \mathrm{~cm}$; G (width): $17.3 \mathrm{~cm}$; F (leg length): $30.59 \mathrm{~cm}$. (C) Colomer Rocher et al., 1988

the European scales established by the Centre interrégional d'information et de recherche en production ovine (color: $1=$ very white, 2 = slightly colored, 3 = partially colored, $4=$ strongly colored; firmness: $1=$ hard, 2 = firm, $3=$ soft, $4=$ very soft and oily) (Carrasco et al., 2009; Sagot and Pottier, 2011a; Sagot and Pottier, 2011b). The results were the means and standard deviations of the subjective and objective measurements recorded for carcasses and meat quality parameters ( $\mathrm{pH}$, temperature, meat color). Meat quality parameters were carried out in triplicates.

\section{RESULTS}

\section{Objective carcass characteristics}

Table I shows the mean values of the live sheep, and hot and cold carcass weights ( $32.55 \mathrm{~kg}, 15.82 \mathrm{~kg}$, and $15.52 \mathrm{~kg}$, respectively), and the percentage of hot and cold dressings, and shrinkage loss (1,9\%). Table II shows the mean values of carcass measurements and indexes.

\section{Subjective carcass characteristics}

Professionals of the meat market seek well-muscled carcasses with an elevated percentage of lean meat and a medium degree of fatness. In

\section{Table I}

Weight characteristics of sheep carcasses of Beni-Guil sheep $(n=105)$, Eastern Morocco

\begin{tabular}{lccc} 
Parameter & Mean \pm SD & Min. & Max. \\
\hline Live weight $(\mathrm{kg})$ & $32.55 \pm 9.33$ & 17.35 & 48.58 \\
Hot carcass weight $(\mathrm{kg})$ & $15.82 \pm 4.8$ & 7.91 & 25.31 \\
Cold carcass weight $(\mathrm{kg})$ & $15.52 \pm 4.7$ & 7.77 & 24.1 \\
Hot dressing $(\%)$ & $48.60 \pm 0.01$ & 43.1 & 51.03 \\
Cold dressing $(\%)$ & $47.68 \pm 0.01$ & 41.89 & 49.96 \\
Shrinkage loss $(\%)$ & $1.90 \pm 0.8$ & 0.66 & 2.91
\end{tabular}

SD: standard deviation; Min.: minimum; Max.: maximum

Table II

Mean values of carcass measurements and calculated carcass indexes of Beni-Guil sheep $(n=105)$,

Eastern Morocco

\begin{tabular}{lrlr} 
Parameter & Mean \pm SD & Min. & Max. \\
\hline Carcass width $(\mathrm{G})(\mathrm{cm})$ & $17.28 \pm 2.56$ & 13 & 23 \\
Carcass length $(\mathrm{K})(\mathrm{cm})$ & $63.70 \pm 6.34$ & 56 & 75 \\
Leg length $(\mathrm{F})(\mathrm{cm})$ & $30.59 \pm 2.39$ & 26 & 35 \\
Leg compactness index & $0.56 \pm 0.10$ & 0.47 & 0.63 \\
$\begin{array}{l}\text { (G/F) } \\
\text { Carcass compactness }\end{array}$ & $0.27 \pm 0.20$ & 0.17 & 0.32 \\
$\begin{array}{l}\text { index1 }(\mathrm{G} / \mathrm{K}) \\
\text { Carcass compactness }\end{array}$ & $243.6 \pm 52.76$ & 138.75 & 277.75 \\
index2 $(\mathrm{CCW} / \mathrm{K})(\mathrm{g} / \mathrm{cm})$ & & &
\end{tabular}

SD: standard deviation; Min.: minimum; Max.: maximum; CCW: cold carcass weight 
our study, as indicated in the methods, a trained assessor had been in charge of subjective carcass evaluation (fatness state, conformation, color, and cover fat). Table III shows the observed subjective traits of Beni-Guil carcasses. According to EUROP fatness scale, the carcass fatness ranged from average to high (mean of 3.42), the conformation was fair to good (mean of 2.39), and the cover fat was white and firm.

\section{Meat quality assessment}

Table IV shows the $\mathrm{pH}$ and color-parameter mean values obtained for Beni-Guil sheep meat.

\section{Table III}

Subjective traits of Beni-Guil sheep carcasses $(n=105)$, Eastern Morocco

$\begin{array}{lccc}\text { Parameter } & \text { Mean } \pm \text { SD } & \text { Min. } & \text { Max. } \\ \text { EUROP conformation score }^{1} & 2.39 \pm 0.49 & 2 & 3 \\ \text { EUROP fatness score }^{2} & 3.42 \pm 0.52 & 2 & 4 \\ \text { Fat color } & \text { White } & - & - \\ \text { Fat firmness } & \text { Firm cover fat } & - & - \\ \text { Carcass color }^{3} & 3.41 \pm 0.48 & 2 & 4\end{array}$

SD: standard deviation; Min.: minimum; Max.: maximum

${ }^{1} \mathrm{E}=5, \mathrm{U}=4, \mathrm{R}=3, \mathrm{O}=2, \mathrm{P}=1 ;{ }^{2} 1=$ very low; $2=$ low; 3 average 4 = high; $5=$ very high; ${ }^{3} 1=$ very light red, $2=$ light red, $3=$ bright red, $4=$ dark red

\section{Table IV}

Mean values of physical parameters of Beni-Guil sheep carcasses $(n=105)$, Eastern Morocco

\begin{tabular}{|c|c|c|c|}
\hline Parameter & Mean \pm SD & Min. & Max. \\
\hline Temperature $\left({ }^{\circ} \mathrm{C}\right)$ & $34.89 \pm 1.10$ & 31.70 & 36.70 \\
\hline $\mathrm{pH} 1$ & $6.76 \pm 0.70$ & 6.67 & 6.91 \\
\hline $\mathrm{pH} 24$ & $5.78 \pm 0.10$ & 5.63 & 5.89 \\
\hline $\mathrm{L}^{*}{\text { (lightness })^{1}}^{1}$ & $41.54 \pm 0.41$ & 40.04 & 42.02 \\
\hline $\mathrm{a}^{*}(\text { redness })^{1}$ & $21.09 \pm 0.47$ & 19.28 & 22.27 \\
\hline$b^{*}(\text { yellowness })^{1}$ & $7.66 \pm 0.47$ & 5.96 & 8.77 \\
\hline Chromaticity $^{2}$ & $22.44 \pm 0.49$ & 20.18 & 23.45 \\
\hline Hue angle ${ }^{3}$ & $19.93 \pm 1.23$ & 17.17 & 22.55 \\
\hline$a * / b *$ & $2.77 \pm 0.19$ & 2.41 & 3.23 \\
\hline
\end{tabular}

SD: standard deviation; Min.: minimum; Max.: maximum

${ }^{1}$ Scales; $a^{*}$ and b*: -60 to $60 ; L^{*}: 0$ to $100 ;{ }^{2}$ Chromaticity: $0-60 ;{ }^{3}$ Hue: $0^{\circ}-360^{\circ}$

\section{DISCUSSION}

In this preliminary study, which aimed to obtain the average data on the objective and subjective quality characteristics of the Beni-Guil sheep carcass, no consideration was given to differences in rearing conditions, slaughter age or slaughter period. Therefore, the collected data represented a general average, without taking into account the possible variations according to the above-mentioned criteria.

The average values of live weight at slaughter, and hot and cold carcass weights showed that the carcass size was small to medium. This carcass type is often sought after in local markets and by consumers in Eastern Morocco. In livestock destined for slaughter, the dressing is a valuable criterion for the quality assessment of sheep carcasses.
Farmers ought to know the importance of carcass yield and chilling loss. In addition, the dressing percentage gives professionals information on potential commercial transactions and profitability. Slaughterhouse traders and butcher retailers often pay for carcass yield.

The $47.7 \%$ cold dressing value was similar to that of $46.5 \%$ recorded in Kivircik sheep, a Turkish breed (Ekiz et al., 2013), and of 49.4\% in Spanish Florida sheep (Peña et al., 2007). Carcass postmortem chilling losses are a major problem in the meat industry. It is caused by drip loss and water evaporation. From an economic point of view, the assessment and mastering of this critical parameter are very important. In this study, the average rate of shrinkage loss was $1.9 \%$ with a minimum of $0.66 \%$ and a maximum of $2.91 \%$. Thus it was low for the Beni-Guil compared to those of $4.92 \%$ for the Chilote Chilean (Ramírez-Retamal et al., 2013), 3.24\% for the Kivircik Turkish (Ekiz et al., 2013), and $2.35 \%$ for the Leccese Italian breeds (D'Alessandro et al., 2013). The low shrinkage loss for the Beni-Guil can be explained by the cover fat quality of carcasses and fatness state, which are related to the breed as an endogenous factor, and to many exogenous factors such as late weaning, animal feeding (grazing contributes to the cover fat hardness), cooling room management, and carcass chilling.

The conformation score is an important parameter for carcass quality assessment (Flamant and Boccard, 1966). In our study the average value of 2.39, with $28.1 \%$ in R-conformation and $71.9 \%$ in O-conformation, reflected a fair to good muscle development. Linear and weight measurements enabled calculating the compactness indexes which confirmed the subjective conformation observed. Furthermore these results showed that Beni-Guil carcasses exhibited good compactness indexes (LCI and CCI2) compared to those reported by Mebirouk-Boudechiche et al. (2008) for the Berber Algerian breed. Nevertheless, LCI, CCI1 and CCI2 values for Beni-Guil sheep were lower than those reported by Alexandre et al. (2008) for the Martinik French breed.

The meat industry requests well-muscled carcasses with a high proportion of lean meat and some degree of fatness to prevent weight loss during cold storage (Peña et al., 2007). The mean fatness score of Beni-Guil carcass was 3.42 according to EUROP fatness scale, with rates of $1.5 \%$ in class $2,54.7 \%$ in class 3 , and $43.8 \%$ in class 4 . The cover fat showed that Beni-Guil carcass had a high fat quality (white and firm), a characteristic well appreciated by professionals and consumers. These results were comparable to those reported by Carrasco et al. (2009) for the Churra Spanish PGI breed.

Meat $\mathrm{pH}$ is a determinant factor for its quality. It affects meat organoleptic proprieties (color, juiciness, tenderness, and flavor). The mean values of $\mathrm{pH} 1$ (6.76) and $\mathrm{pH} 24$ (5.78) showed normal postmortem glycolysis of Beni-Guil sheep meat, and reflected normal (stressless) slaughter conditions in Eastern Moroccan slaughterhouses. These results are comparable to values reported by other authors (Žgur et al., 2003; Mazzette et al., 2005; Sen et al., 2011). Similarly, color is the best indicator for meat quality and freshness (Clinquart et al., 2000; Coibion, 2008). Consumers often use it as a quality index as it varies depending on the muscle $\mathrm{pH}$ evolution. The ultimate $\mathrm{pH}(\mathrm{pH} 24)$ is closely related with meat color, because it has a direct influence on muscle protein weft (superficial state of the meat) and consequently on light penetration into muscle. A pH24 close to the $\mathrm{pHi}$ (isoelectric) of meat protein allows a good light reflection, thus the bright red meat color sought after by meat markets.

In this study, the subjective results obtained for the carcass meat color matched the objective measurements. There was a predominance of the red color ( $\mathrm{a}^{*} / \mathrm{b}^{*}$ ratio), oxymyoglobin richness (hue angle), and optimal meat color (chromaticity) (Salifou et al., 2013). Our results for meat color agreed with those of Moëvi (2006) who reported values of 28-30 for dark red meat and 50-55 for very light red meat. 
The halal slaughtering method can partially explain this result as it enables blood evacuation and thus decreases muscle pigment concentration. Calnan et al. (2016) observed that an increase in myoglobin concentration increases the red color intensity.

\section{CONCLUSION}

These results constitute a preliminary study on carcass and meat characterization of Beni-Guil sheep reared and slaughtered in Eastern Morocco. This breed has an average conformation, a medium to high fatness state and a high quality of carcass cover fat. Protected by the PGI label, it is well adapted to sheep transhumance and constitutes the main source of food and income for rural farmers in the area, particularly for local people who continue to live in a very traditional way as nomadic breeders.

\section{Acknowledgments}

We are grateful to Wallonie Bruxelles International for the financial support (WBI-Project 1-6, 2015-2017). Our thanks are also due to the Office national de sécurité sanitaire des produits alimentaires, Eastern area, and slaughterhouse staffs for facilitating access to facilities, supervision of this work, and practical assistance. Equal thanks go to ANOC for their collaboration.

\section{Conflicts of interest}

The authors declare that there are no conflicts of interest associated with this study.

\section{Author contributions statement}

$\mathrm{KB}$ and $\mathrm{AE}$ conceived and designed the work; $\mathrm{KB}$, AT and $\mathrm{AO}$ collected the data; KB and FM analyzed and/or interpreted the data; KB and $\mathrm{AE}$ drafted the article; $\mathrm{CHS}$ and $\mathrm{MB}$ critically revised the article.

\section{REFERENCES}

Alexandre G., Bocage B., Coppry O., Weisbecker J.L., Mahieu M., Archimède H., 2008. Parameters of carcass cuts and measurements of Martinik lambs managed under intensive conditions. Rev. Elev. Med. Vet. Pays Trop., 61 (2): 121-126, doi: 10.19182/remvt.9998

ANOC, 2018. Beni Guil « Daghma ». Association nationale ovine et caprine, www.anoc.ma/les-races/races-ovines/beni-guil/ (accessed 7 Jul. 2018)

Belhaj K., Mansouri F., Ben Moumen A., Fauconnier M.-L., Boukharta M., Caid H.S., Sindic M., et al., 2018. Physicochemical and nutritional characteristics of Beni Guil lamb meat raised in eastern Morocco. Mediterr. J. Nutri. Metab., 11: 175-185, doi: 10.3233/MNM-17195

Boujenane I., 2005. Small ruminant breeds of Morocco. In: Characterization of small ruminant breeds in West Asia and North Africa (Ed. Iniguez L.). Institut agronomique et vétérinaire Hassan II, Rabat, Morocco, 454-497

Boujenane I., Berrada D., Mihi S., Jamai M., 1998. Reproductive performance of ewes and preweaning growth of lambs from three native Moroccan breeds mated to rams from Moroccan and improved breeds. Small Rumin. Res., 27 (3): 203-208, doi: 10.1016/S0921-4488(97)00052-7

Boulanouar B., Paquay R., 2006. L'élevage du mouton et ses systèmes de production au Maroc. Institut national de la recherche agronomique, Rabat, Morocco, $348 \mathrm{p}$.

Calnan H., Jacob R.H., Pethick D.W., Gardner G.E., 2016. Production factors influence fresh lamb longissimus colour more than muscle traits such as myoglobin concentration and pH. Meat Sci., 119: 41-50, doi: 10.1016/j. meatsci.2016.04.009
Carrasco S., Ripoll G., Sanz A., Alvarez-Rodríguez J., Panea B., Revilla R., Joy M., 2009. Effect of feeding system on growth and carcass characteristics of Churra Tensina light lambs. Livest. Sci., 121 (1): 56-63, doi: 10.1016/j. livsci.2008.05.017

Cezar M.F., Sousa W.H., 2007. Carcaças ovinas e caprinas: obtenção, avaliação e classificação. Agropecuária Tropical, Uberaba, Brazil, 231 p.

Clinquart A., Leroy B., Dottreppe O., Hornick J.L., Dufrasne I., Istasse L., 2000. Les facteurs de production qui influencent la qualité de la viande des bovins Blanc Bleu Belge. In : Journée Cesam L'élevage du Blanc Bleu Belge, 26 mai 2000. Cesam, Paris, France, 19 p.

Coibion L., 2008. Acquisition des qualités organoleptiques de la viande bovine : adaptation à la demande du consommateur. Thèse Doct., Ecole nationale vétérinaire, Toulouse, France, $97 \mathrm{p}$.

Colomer-Rocher F., Morand-Fehr P., Kirton A.H., Delfa R., Sierra Alfranca I., 1988. Métodos normalizados para el estudio de los caracteres cuantitativos y cualitativos de las canales caprinas y ovinas. Cuadernos INIA, 17: 9-41

D'Alessandro A.G., Maiorano G., Ragni M., Casamassima D., Marsico G., Martemucci G., 2013. Effects of age and season of slaughter on meat production of light lambs: Carcass characteristics and meat quality of Leccese breed. Small Rumin. Res., 114 (1): 97-104, doi: 10.1016/j.smallrumres.2013.05.006

Ekiz B., Demirel G., Yilmaz A., Ozcan M., Yalcintan H., Kocak O., Altinel A. 2013. Slaughter characteristics, carcass quality and fatty acid composition of lambs under four different production systems. Small Rumin. Res., 114 (1): 26-34, doi: 10.1016/j.smallrumres.2013.05.011

Flamant J.-C., Boccard R., 1966. Estimation de la qualité de la carcasse des agneaux de boucherie. Ann. Zootech., 15 (1) : 89-113, doi : 10.1051/animres:19660106

Guessous F., Boujenane I., Bourfia M., Narjisse H., Khaldi G., Aboul-Naga A.N., 1989. Small ruminants in the Near East. FAO, Rome, Italy, 147 p.

HCP (Haut-Commissariat au Plan), 2017. Le Maroc en chiffres. www.hcp. ma/file/198609/ (accessed 16 June 2018)

Mazzette R., Meloni D., De Santis E.P.L., Santercole V., Scarano C., Cosseddu A.M., 2005. Characterization of Sarda sheep carcasses used in the processing of meat products. Vet. Res. Commun., 29 (2): 335-338, doi: 10.1007/s11259-005-0075-4

Mebirouk-Boudechiche L., Araba A., Ouzrout R., 2008. Influence of the type of energy supplementation (date stones vs barley) on fattening performances and carcass characteristics of fattening Berber Lambs. Rev. Elev. Med. Vet. Pays Trop., 61 (3-4): 209-214, doi: 10.19182/remvt.9991

Moëvi I., 2006. Le point sur la couleur de la viande bovine. Interbev, Institut de l'élevage, Paris, France, 113 p.

Peña F., Perea J., García A., Acero R., 2007. Effects of weight at slaughter and sex on the carcass characteristics of Florida suckling kids. Meat Sci., 75 (3): 543-550, doi: 10.1016/j.meatsci.2006.09.004

Ramírez-Retamal J., Morales R., Martínez M.E., de la Barra R., 2013. Effect of breed and feeding on the carcass characteristics of the Chilote breed lamb. Chil. J. Agr. Res., 73 (1): 48-54, doi: 10.4067/S0718-58392013000100007

Sagot L., Pottier E., 2011a. La grille de notation de la fermeté du gras des carcasses. http://idele.fr/rss/publication/idelesolr/recommends/la-grille-de-notation-de-la-fermete-du-gras-des-carcasses.html (accessed 22 Oct. 2018)

Sagot L., Pottier E., 2011b. La grille de notation de la couleur du gras des carcasses. Idem 2011a

Salifou C.F.A., Youssao A.K.I., Ahounou S.G., Tougan P.U., Farougou S., Mensah G.A., Clinquart A., 2013. Critères d'appréciation et facteurs de variation des caractéristiques de la carcasse et de qualité de la viande bovine. Ann. Méd. Vét., 157 : 27-44

Sen U., Sirin E., Ulutas Z., Kuran M., 2011. Fattening performance, slaughter, carcass and meat quality traits of Karavaka lambs. Trop. Anim. Health Prod., 43 (2): 409-416, doi: 10.1007/s11250-010-9707-y

Žgur S., Cividini A., Kompan D., Birtič D., 2003. The effect of live weight at slaughter and sex on lambs carcass traits and meat characteristics. Agric. Conspec. Sci., 68 (3): 155-159 


\section{Résumé}

Belhaj K., Mansouri F., Tikent A., Ouchatbi A., Boukharta M., Serghini C.H., Elamrani A. Caractéristiques qualitatives de la carcasse de mouton Beni-Guil, produit certifié Indication géographique protégée de l'est du Maroc : étude préliminaire

L'objectif de l'étude a été d'évaluer pour la première fois les caractéristiques qualitatives, objectives et subjectives de la carcasse et de la viande de la race ovine Beni-Guil, originaire de l'est du Maroc. L'étude a été réalisée avec 105 agnelles et brebis âgées en moyenne de 21,5 mois (8-36 mois) et d'un poids moyen de $32,55 \mathrm{~kg}$. Les mesures du $\mathrm{pH}$ ont été prises une heure et 24 heures après I'abattage. Les valeurs moyennes obtenues ont été respectivement de 6,76 et 5,78. Les poids moyens de la carcasse chaude (PCC) et froide (PCF), et les rendements correspondants ont été respectivement de 15,82 kg $(48,6 \%)$ et $15,52 \mathrm{~kg}(47,7 \%)$. La perte de poids au refroidissement a été de 1,9\%. Les mesures linéaires ont montré que la Beni-Guil avait en moyenne une longueur (K) et une largeur (G) de carcasse respectivement de 63,7 et $17,3 \mathrm{~cm}$, avec des indices de compacité de carcasse $1(\mathrm{G} / \mathrm{K})$ et 2 (PCF/K) respectivement de 0,27 et 243,60 g/cm. Enfin, selon la grille de classification des carcasses ovines EUROP, les carcasses examinées ont présenté des conformations les situant entre les classes assez bonne $(\mathrm{O})$ et bonne $(\mathrm{R})$, une couleur rouge vif, un gras de couverture blanc et ferme, et une note d'engraissement de 3,42. Les résultats ont révélé les caractéristiques de la carcasse de la brebis Beni-Guil, lesquelles sont recherchées par les professionnels et les consommateurs.

Mots-clés : ovin Beni-Guil, carcasse, qualité de la viande, appellation d'origine, Maroc

\section{Resumen}

Belhaj K., Mansouri F., Tikent A., Ouchatbi A., Boukharta M., Serghini C.H., Elamrani A. Características de calidad de las carcasas de ovejas Beni-Guil, producto de Indicación Geográfica Protegida certificada del este de Marruecos: estudio preliminar

El objetivo del estudio fue evaluar, por la primera vez, las características objetivas y subjetivas de la calidad de la carcasa y la carne de la raza de ovejas Beni-Guil, originaria del este de Marruecos. El estudio se condujo con 105 ovejas y corderos hembras con una edad promedio de 21,5 meses (8-36 meses), y con un peso medio de $32,55 \mathrm{~kg}$. Se tomaron medidas de $\mathrm{pH}$ una hora y 24 horas después del sacrificio. Los valores promedio obtenidos fueron 6,76 y 5,78 respectivamente. Los pesos medios de las carcasas calientes (PCC) y frías (PCF) y correspondientes rendimientos fueron $15,82 \mathrm{~kg}$ $(48,6 \%)$ y $15,52(47,7 \%)$ respectivamente. La pérdida por contracción fue de 1,9\%. Las medidas lineares mostraron que las Beni-Guil presentaron una longitud media de la carcasa (K) y un ancho (G) de 63,7 y $17,3 \mathrm{~cm}$ respectivamente, con un índice de compactibilidad de $1(\mathrm{G} / \mathrm{K})$ y 2 (PCF/K) de 0,27 y 243,60 g/cm respectivamente. Finalmente, según la tabla de clasificación EUROP, las carcasas examinadas mostraron conformaciones entre bastante buena $(\mathrm{O})$ y buena $(\mathrm{R})$, un color rojo vivo, una capa de grasa blanca firme y un índice graso de 3,42 . Los resultados subrayan las características de las carcasas de ovejas Beni-Guil, apreciadas por profesionales y consumidores.

Palabras clave: ovino Beni-Guil, canal animal, calidad del aire, denominación de origen, Marruecos 